\title{
Evaluation of clinical course, histopathological and treatment characteristics of patients with Kaposi's sarcoma
}

\author{
Kaposi sarkomu tanısı alan hastaların klinik seyir, histopatolojik ve tedavi özelliklerinin \\ değerlendirilmesi
}

\section{Asude Kara Polat, ๑ Müge Göre Karaali, ๑ Ayșe Esra Koku Aksu, ๑ Cem Leblebici*,} (1) Mehmet Salih Gürel**

Istanbul Training and Research Hospital, Clinic of Dermatology; *Clinic of Pathology, Istanbul, Turkey **istanbul Medeniyet University, Göztepe Training and Research Hospital, Clinic of Dermatology, İstanbul, Turkey

\begin{abstract}
Background and Design: Kaposi's sarcoma (KS) is an angioproliferative disease of vascular endothelium associated with human herpes virus-8 (HHV-8). The purpose of this study was to evaluate the clinical course, histopathological and treatment characteristics in patients with KS. Materials and Methods: A retrospective study was conducted on 77 patients with KS who attended the Dermatology Outpatient Clinic in the İstanbul Training and Research Hospital between April 2008 and December 2016. The clinical course, histopathological and treatment characteristics were evaluated from the hospital records.

Results: The mean age of the patients was $67.4 \pm 13.8$ years. $67.5 \%$ of patients were male and $32.5 \%$ were female. Five patients (6.5\%) had oral mucosal involvement. Human immunodeficiency virus positivity was detected in 4 patients (5.2\%). HHV-8, CD-31 and CD-34 positivity were detected in $94.0 \%, 98.0 \%$ and $84.2 \%$ of patients, respectively. Three patients (3.9\%) had secondary malignancy (1 patient had lymphoma, 1 had thyroid carcinoma and 1 had bladder carcinoma). The most commonly used treatments were cryotherapy (26.3\%) as monotherapy, and excision and cryotherapy (14.8\%) as combination therapy.

Conclusion: Clinical and histopathological features are important in establishing the diagnosis of KS. In our study, the rate of unresponsiveness to treatment observed in follow-up was low and progression was rare. Screening and follow-up of the secondary malignancies that may accompany KS should be carried out with caution.
\end{abstract}

Keywords: Kaposi's sarcoma, histopathology, HHV-8, immunohistochemistry, secondary malignancy, treatment

\section{Öz}

Amaç: Kaposi sarkomu (KS) vasküler endotelin human herpes virüs-8 (HHV-8) ile ilişkili etiyopatogenezi tam olarak bilinmeyen anjiyoproliferatif bir hastalı̆̆ıdır. Ülkemizde dermatoloji kliniklerinden KS ile ilgili sınılı sayıda çalışma bulunmaktadır. Bu çalışma ile İstanbul ilinde KS'nin klinik seyir, histopatoloji ve tedavi özelliklerinin değerlendirilmesi amaçlanmıştır.

Gereç ve Yöntem: Nisan 2008-Aralık 2016 tarihleri arasında dermatoloji polikliniğine başvurmuş ve KS tanısı almış olan 77 hastanın klinik seyri, histopatoloji ve tedavi özellikleri hastane otomasyon sistemindeki kayıtlardan retrospektif olarak incelenmiştir.

Bulgular: Yetmiş yedi hastanın 25'i $(\% 32,5)$ kadın, 52'si $(\% 67,5)$ erkek olup, yaş ortalamaları $67,4 \pm 13,8$ idi. Beş hastada $(\% 6,5)$ oral mukozal tutulum bulunmakta idi. İnsan immün yetmezlik virüsü pozitifliği hastaların 4 'ünde $(\% 5,2)$ saptanmış olup, bu hastalarda mukozal ve visseral tutulum yoktu. İmmünohistokimyasal olarak değerlendirilen hastalarda HHV-8, CD-31 ve CD-34 pozitifliği sırası ile \%94,0, \%98,0 ve \%84,2 saptandı. Çalışmamızda hastaların 3'ünde $(\% 3,9)$ sekonder malignite (bir hastada lenfoma, bir hastada tiroid karsinomu ve bir hastada mesane karsinomu) mevcuttu. En sık kullanılan tedavi yöntemi monoterapi olarak kriyoterapi $(\% 20,8)$, kombine tedavi olarak ise eksizyon ve kriyoterapi $(\% 11,7)$ idi.

Sonuç: KS tanısında klinik ve histopatolojik özellikler önemlidir. Çalışmamızda KS hastalarının takibinde tedaviye yanıtsızlık oranı düşük ve progresyon nadir olarak görülmektedir. KS'ye eşlik edebilecek sekonder malignitelerin tarama ve takibi dikkatli yapılmalıdır.

Anahtar Kelimeler: Kaposi sarkomu, histopatoloji, HHV-8, immünohistokimya, sekonder malignensi, tedavi

Address for Correspondence/Yazışma Adresi: Asude Kara Polat MD, İstanbul Training and Research Hospital, Clinic of Dermatology, İstanbul, Turkey Phone: +90 5052512142 E-mail: asudekara@yahoo.com.tr Received/Geliş Tarihi: 03.01.2018 Accepted/Kabul Tarihi: 20.06.2018 ORCID ID: orcid.org/0000-0002-5040-6901

CCopyright 2018 by Turkish Society of Dermatology and Venereology

Turkderm-Turkish Archives of Dermatology and Venereology published by Galenos Yayınevi. 


\section{Introduction}

Kaposi sarcoma (KS), first defined by Moritz Kaposi in 1872, is a human herpes virus-8 (HHV-8) associated angioproliferative disorder of vascular endothelium. It is typically seen in elderly men'.

$\mathrm{HHV}-8$ virus is the principal etiological agent of the disorder, followed by various genetic, environmental, immunological risk factors. However, the underlying etiopathogenesis remains unknown. It has four epidemiological types: the classical, endemic (African type), epidemic [acquired immune deficiency syndrome (AIDS)-associated], and iatrogenic $\mathrm{KS}^{2,3}$.

While KS may present as a solitary lesion, it may also present in a disseminated cutaneous form. Lesions may appear as violet erythematous macules, papules, plaques, nodules, or tumors. The disease is typically confined to the skin but it may also invade visceral organs and mucosae ${ }^{1}$.

The diagnosis is made by clinical and histopathological correlation. The treatment includes several local or systemic treatment options depending on disease extent and clinical form ${ }^{4}$.

This study retrospectively evaluated the clinical, histopathological, and treatment properties in 77 patients with KS who attended the dermatology outpatient clinic in the İstanbul Training and Research Hospital, between April 2008 and December 2016.

\section{Materials and Methods}

This study retrospectively reviewed the digital records and medical information of 77 patients with KS who attended the Dermatology Outpatient Clinic in the İstanbul Training and Research Hospital between April 2008 and December 2016. The study was approved by the İstanbul Training and Research Hospital, Scientific Research and Publication Ethics Committee (approval number: 932, date: 27.07.2017). Missing patient information were obtained by telephone interviews. Written informed consent have been obtained from the patients. The socio-demographic, clinical, and treatment properties were recorded in a database specifically designed for the study:

Socio-demographic properties: Age, sex, marital status, smoking and alcohol use, comorbidities (dermal and/or systemic disorders).

Clinical characteristics and laboratory findings: Disease duration (months), duration of follow-up (months), lesion number and location, mucosal involvement, accompanying symptoms, type of clinical disease (classical, AIDS-associated, iatrogenic, endemic), histopathological stage (patch, plaque, nodule), and HHV-8, CD31, and CD34 positivity in immunohistochemical study.

Treatment data: Type of treatment (conservative management, surgical treatment, radiotherapy, systemic therapy), medication side effects, response to initial treatment (complete response, partial response, stable disease, progressive disease), durability of response (stable complete response, recurrence).

\section{Statistical Analysis}

Data analyses were performed with statistical software SPSS 22.0. Comparisons between two independent groups were made by Student's t-test and the Mann-Whitney $U$ test. Comparisons of two dependent groups were made by the Wilcoxon test. Ratios of categorical variables between groups were tested by chi-square test.
Under the circumstances where conditions could not be fulfilled, Fisher's exact test was applied. A p value of less then 0.005 was considered statistically significant.

\section{Results}

\section{Socio-demographic properties}

Of the 77 patients enrolled in the study, 25 (32.5\%) were female and $52(67.5 \%)$ were male. The mean age was $67.4 \pm 3.8$ years and the mean follow-up duration was 19.1 \pm 11.6 months (Table 1).

Three $(3.9 \%)$ patients had a history of malignancy, which were lymphoma, urinary bladder carcinoma, and thyroid papillary carcinoma. Additionally, 1 patient had Castleman disease (CD), and another had myelodysplastic syndrome. The most common comorbid systemic disorders were hypertension ( $n=16,20.8 \%$ ) and diabetes mellitus (DM) $(n=10,13.0 \%)$.

Four (5.2\%) patients with a mean age of $41.0 \pm 8.5$ years (29-48), all of whom were male, had human immunodeficiency virus (HIV) infection. HIV-positive patients were significantly younger than the HIV-negative ones $(p<0.05)$.

\section{Clinical properties}

The distribution of lesion number was as follows: 12 (15.6\%) patients had a solitary lesion; 15 (19.5\%) had 2-5 lesions; and 50 (64.9\%) had $>5$ lesions.

The lesion location was as follows: in the lower extremity alone in 43 (55.8\%) patients, in the upper extremity alone in $6(7.8 \%)$ patients, and in the trunk alone in $1(1.3 \%)$ patient. The number of patients with both upper and lower extremity involvement was 25 (32.5\%). Four patients had genital involvement ( 2 had scrotal and 2 had penile shaft involvement). A total of 5 (6.5\%) patients had mucosal involvement, all of which were oral mucosal involvement (2 had buccal mucosal, 2 had glossal, and 1 had hard palatal involvement). All mucosal and genital involvements were observed in male patients.

There was no statistically significant difference in lesion location between male and female patients $(p>0.05)$. No visceral involvement was found in any of our patients. Clinical photographs of patients with $\mathrm{KS}$ at various locations were shown in Figure 1, and the photographs of clinical, histopathological, and confocal properties of a patient with a classical KS were shown in Figure 2.

Table 1. The socio-demographic properties of the study population

\begin{tabular}{|l|l|}
\hline $\mathbf{n = 7 7}$ & $\mathbf{n}(\mathbf{\%})$ \\
\hline $\mathbf{S e x}$ & \\
Female & $25(32.5 \%)$ \\
Male & $52(67.5 \%)$ \\
\hline Age & $67.4 \pm 13.8$ \\
\hline Disease duration (months) & $19.1 \pm 11.6$ \\
\hline Duration of follow-up (months) & $26.8 \pm 25.9$ \\
\hline Smoking & $32(41.6 \%)$ \\
\hline Alcohol use & $24(31.2 \%)$ \\
\hline Additional dermatological disease & $14(18.2 \%)$ \\
\hline Additional systemic disease & $47(61.0 \%)$ \\
\hline n: Number of the patients & \\
\hline
\end{tabular}


An assessment of lesion location in 4 HIV-positive patients revealed that all patients with HIV had lower extremity lesions. Two patients had upper extremity, head-neck, and trunk involvement additionally. None had mucosal or visceral involvement. All patients were asymptomatic. Clinical photographs of a HIV-positive KS patient were shown in Figure 3.

Histopathological examination showed that 42 patients had nodules; a separate analysis of HIV-positive patients revealed that 3 (75\%) had lesions at the plaque stage (Table 2).

The immunohistochemical examination revealed that 47 (94.0\%) of 50 patients were HHV-8-positive; 50 (98.0\%) of 51 patients were CD-31positive; and 16 (84.2\%) of 19 patients were CD-34-positive.

\section{Table 2. Clinical properties of the study population} $\mathrm{n}(\%)$

\begin{tabular}{|l|l|}
\hline \multicolumn{2}{|l|}{ Lesion number } \\
\hline 1 & $12(15.6)$ \\
$2-5$ & $15(19.5)$ \\
$>5$ & $50(64.9)$ \\
\hline
\end{tabular}

\begin{tabular}{|c|c|}
\hline \multicolumn{2}{|l|}{ Lesion location } \\
\hline $\begin{array}{l}\text { Lower extremity } \\
\text { Upper extremity } \\
\text { Trunk } \\
\text { Head-neck } \\
\text { Genital region } \\
\text { Mucosa }\end{array}$ & $\begin{array}{l}70(90.9) \\
31(40.3) \\
12(15.6) \\
6(7.8) \\
4(5.2) \\
5(6.5)\end{array}$ \\
\hline \multicolumn{2}{|l|}{ Symptoms } \\
\hline $\begin{array}{l}\text { Bleeding } \\
\text { Edema } \\
\text { Ulceration } \\
\text { Itching } \\
\text { Pain } \\
\text { Asymptomatic }\end{array}$ & $\begin{array}{l}15(19.5) \\
10(13.0) \\
10(13.0) \\
6(7.8) \\
5(6.5) \\
48(62.3)\end{array}$ \\
\hline \multicolumn{2}{|c|}{ Histopathological stage } \\
\hline $\begin{array}{l}\text { Nodule } \\
\text { Plaque } \\
\text { Patch }\end{array}$ & $\begin{array}{l}42(54.5) \\
28(36.4) \\
7(9.1)\end{array}$ \\
\hline
\end{tabular}

\section{Treatment properties}

Since 11 patients were treated conservatively and 5 others had unknown treatment properties, the treatment properties of 61 patients were analyzed. Forty-four (72.3\%) patients received monotherapy and $17(27.7 \%)$ received a combination therapy. The most commonly used monotherapy was cryotherapy $(n=16,26.3 \%)$. The combination of excision and cryotherapy was used in 9 patients, representing the most common combination treatment. Table 3 summarizes treatments and treatment responses.

All HIV-positive patients received antiretroviral treatment, and 2 received combined treatment (1 patient received radiotherapy and 1 cryotherapy).

Considering all treatments applied, 30 (49.2\%) of 61 patients showed complete treatment response. Four (6.6\%) patients ( 3 males, 1 female) with complete treatment response experienced local recurrence; three of them were treated with excision and 1 with cryotherapy.
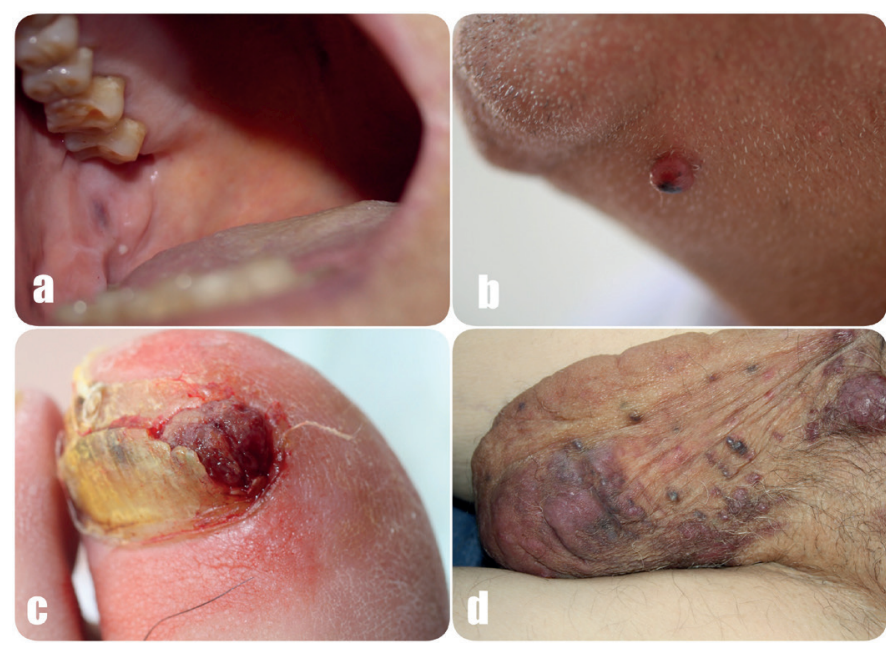

Figure 1. Clinical photographs of patients with Kaposi's sarcoma (KS) at various locations: a) a $5 \mathrm{~mm}$ violet macule on the right buccal mucosa, b) a KS lesion with a diameter of $5 \mathrm{~mm}$ in the submental region, c) a bleeding, violet nodule located on the toe of the left foot. d) Multiple violet papules and nodules in scrotum

Table 3. Treatment modalities and treatment responses

\begin{tabular}{|c|c|c|c|c|c|}
\hline $\begin{array}{l}\text { Complete } \\
\text { response }\end{array}$ & $\begin{array}{l}\text { Partial } \\
\text { response }\end{array}$ & Unresponsive & Progressive & Unknown & n (\%) \\
\hline- & - & - & - & - & $44(72.3)$ \\
\hline $\begin{array}{l}4 \\
14 \\
1 \\
0 \\
0 \\
\end{array}$ & $\begin{array}{l}10 \\
0 \\
7 \\
2 \\
1 \\
\end{array}$ & $\begin{array}{l}1 \\
0 \\
1 \\
0 \\
0\end{array}$ & $\begin{array}{l}0 \\
0 \\
1 \\
0 \\
0\end{array}$ & $\begin{array}{l}1 \\
0 \\
0 \\
0 \\
1\end{array}$ & $\begin{array}{l}16(26.3) \\
14(22.9) \\
10(16.5) \\
2(3.3) \\
2(3.3)\end{array}$ \\
\hline- & - & - & - & - & $17(27.7)$ \\
\hline $\begin{array}{l}4 \\
1 \\
1 \\
1 \\
0 \\
1 \\
1\end{array}$ & $\begin{array}{l}5 \\
0 \\
2 \\
0 \\
1 \\
0 \\
0\end{array}$ & $\begin{array}{l}0 \\
0 \\
0 \\
0 \\
0 \\
0 \\
0\end{array}$ & $\begin{array}{l}0 \\
0 \\
0 \\
0 \\
0 \\
0 \\
0\end{array}$ & $\begin{array}{l}0 \\
0 \\
0 \\
0 \\
0 \\
0 \\
0\end{array}$ & $\begin{array}{l}9(14.8) \\
1(1.6) \\
3(4.9) \\
1(1.6) \\
1(1.6) \\
1(1.6) \\
1(1.6)\end{array}$ \\
\hline
\end{tabular}

$\mathrm{n}$ : Number of the patients, CT: Chemotherapy, RT: Radiotherapy 


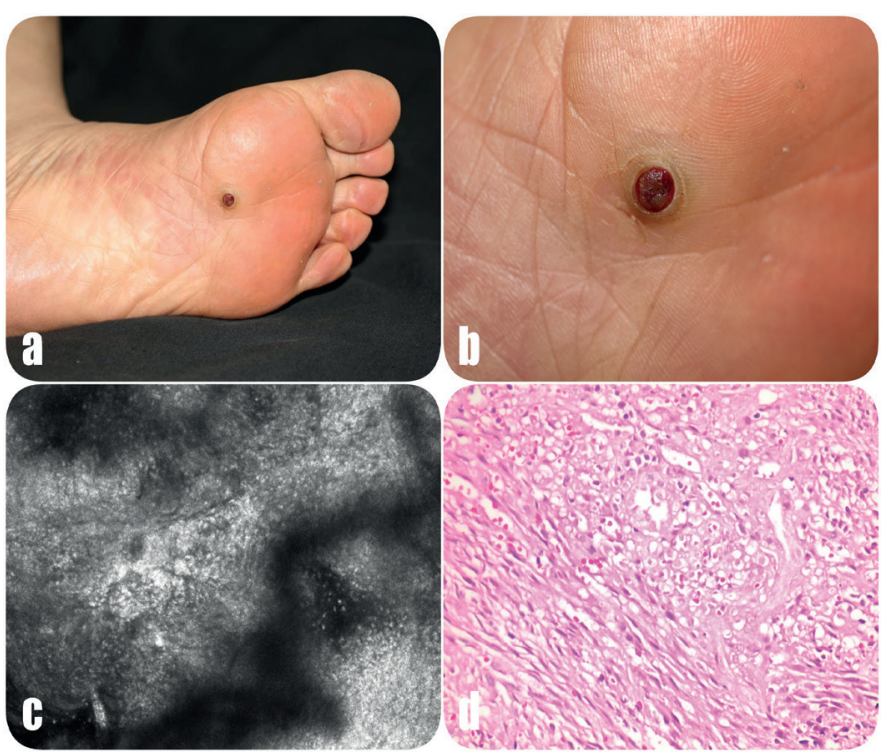

Figure 2. Photographs showing the clinical, histopathological, and confocal properties of a patient with a classical Kaposi's sarcoma (KS): a) a violet protruding papule in the plantar region of the left foot, b) closer view of the lesion, c) a reflectance confocal microscopic image of the patient with $\mathrm{KS}, \mathrm{d}$ ) spindle cell vascular proliferation, cleft-like vascular spaces, and erythrocyte extravasation in dermis

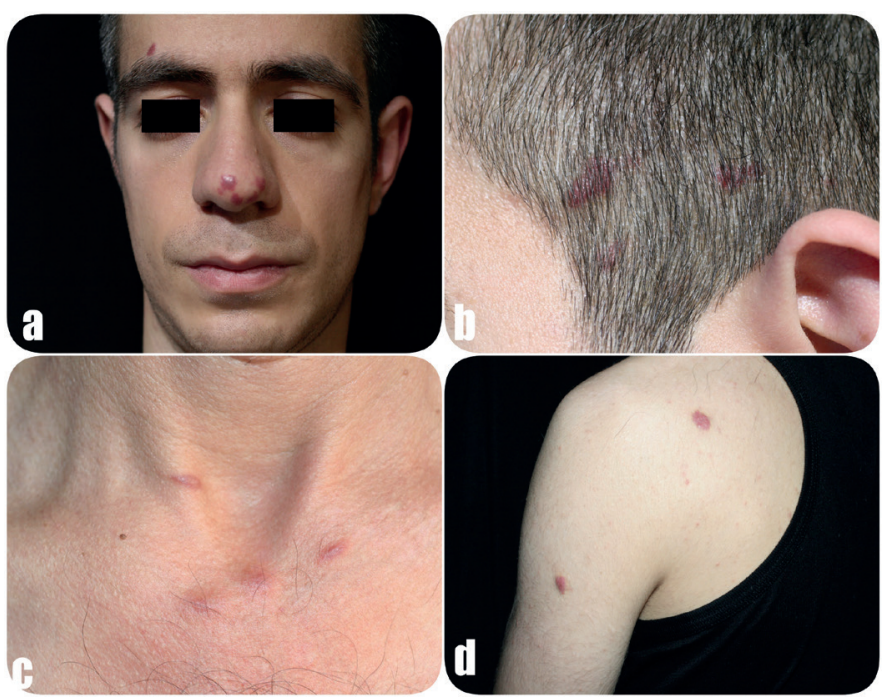

Figure 3. Photographs of a HIV-positive Kaposi's sarcoma (KS) patient: a) KS lesions of the nose and right brow, b) KS lesions on the frontotemporal region, c) four KS lesions around the jugular region, d) KS lesions on the left shoulder and the extensor surface of the arm

\section{Follow-up properties}

KS was fatal in 10 (13\%) of 77 patients over a follow-up period of 26.8 months. Of these, 1 (1.3\%) died due to an accompanying secondary malignancy (lymphoma), 1 (1.3\%) patient died due to neutropenia and pneumonic complications secondary to chemotherapy used for diffuse KS disease, and the remainders due to other medical conditions accompanying the clinical presentation.

\section{Discussion}

KS was first defined by Moritz Kaposi in 1872, and is typically characterized by vascular skin lesions of low malignant potential. It particularly affects elderly men of Italian, Jewish, or Mediterranean descent ${ }^{3,5}$. Its incidence varies by geographical region. In a study of a Jewish population, its incidence was reported to be 20.7 per million in men and 7.5 per million in women 6 .

In a multicenter study from Europe, its incidence in the general population was reported to be 3.0 per million? ${ }^{7}$. There is no study about its prevalence and incidence in Turkey although there are some demographic, clinical, and histopathological studies ${ }^{8-10}$.

$\mathrm{KS}$ is more prevalent in men, with male/female ratio being greater in the classical KS than in AIDS-related $\mathrm{KS}^{3}$. Among patients with the classical KS in our study, the male/female ratio was $2.08 \%$, which was lower than previously reported ${ }^{8,11}$

The mean age of our patients with the classical KS was 68.8 years, which was similar to that in most of studies reported previously but greater than that reported by Wu et al.,3,11,12 KS patients with HIV positivity had a mean age of 41 years, which was similar to that reported by Akinde et al. ${ }^{5}$ among HIV - positive KS patients.

It has been reported that KS may be accompanied by secondary malignancies ${ }^{13}$. The reported prevalence of concurrent malignancies varies between $8.6 \%$ and $37.0 \%$ whereas we reported a lower prevalence, $3.9 \%^{11,12,14}$. The lower prevalence may be due to the short follow-up duration in our study.

Among studies performed by dermatology clinics in Turkey, Su et al. ${ }^{9}$ reported a concurrence of colonic and gastric adenocarcinoma while Demirel et al. ${ }^{8}$ reported concurrent colonic and prostate adenocarcinoma. In our study population, a patient had lymphoma, a patient had thyroid carcinoma, and another had urinary bladder carcinoma. Weissmann et al. ${ }^{12}$ reported 4 urinary bladder cancers among 21 concurrent malignancies.

Paradžik et al. ${ }^{15}$ reported HHV-8 positivity in urinary bladder tissues among 55\% of patients with bladder cancer. Furthermore, some studies have reported that HHV-8 positivity may be associated with drug resistance in bladder carcinoma ${ }^{16}$. Although more studies are needed, this shows that clinicians must be vigilant for bladder cancer development in patients with $\mathrm{KS}$.

$C D$ is a benign lymphoproliferative disease whose etiology involves HHV-8 positivity as KS, although its malignancy category is controversial ${ }^{17}$. Weissmann et al. ${ }^{12}$ reported $C D$ among secondary malignancies accompanying $\mathrm{KS}$, and we found co-existence of $\mathrm{KS}$ and $C D$. It is recommended that patients with $C D$ be monitored for the development of KS due to similar etiologies of both conditions ${ }^{18}$. $\mathrm{DM}$ has been reported to increase the risk of $\mathrm{KS}^{19,20}$. We found that $13 \%$ of our patients had DM, and the incidence range provided by studies in dermatology clinics from Turkey is $11.1 \%$ to $12.1 \% 8,9$. Smoking, on the other hand, has been reported to be a risk factor for developing KS. Our study determined a greater prevalence (41.6\%) of smoking than previous studies 8,9

KS can affect mucocutaneous and visceral organs and frequently shows a mucocutaneous involvement. In accordance with literature reports, our patients' lesions had mucocutaneous location. Lower extremities were the most common predilection site in the classical and AIDSassociated $\mathrm{KS}^{11,21}$. None of our patients showed visceral involvement. 
None of our HIV - positive patients had mucosal or visceral involvement. According to our opinion, this is due to a low number of HIV - positive cases enrolled in our study.

Most of our patients were asymptomatic (62.3\%). The most common symptom was bleeding, affecting $19.5 \%$ of the study population. This was followed by edema (13.9\%) and ulceration (13\%). A study on KS patients reported from Peru identified edema as the most common symptom. A study from Turkey reported edema at a rate of $44 \%$ while another one reported bleeding to be the most common symptom $(5.4 \%)^{8,9,11}$

KS has 3 histopathological stages: patch stage, plaque stage, and nodular stage 22 . Prior studies reported the rate of $36-87.5 \%$ for the nodular stage of the classical KS $\mathrm{KS}^{21,23,24}$. We also identified the nodular stage as the most common stage, with a rate of $53.2 \%$. Akinde et al. ${ }^{5}$ reported the plaque stage as the most commonly encountered stage among HIV - positive patients with $\mathrm{KS}$. We similarly identified the plaque stage in $75 \%$ of HIV - positive patients.

Considered an oncogenic virus, HHV-8 is detected in every form of KS. Various growth factors and proteins regulating cell cycle and inhibiting apoptosis encoded by viral genome have been identified ${ }^{25,26}$. Hiatt et al. ${ }^{21}$ reported HHV-8 positivity among 40 of 41 patients randomly selected by the polymerase chain reaction method while Demirel et al. ${ }^{8}$ reported HHV-8 positivity among $89.2 \%$ patients examined by immunohistochemistry. We also detected HHV-8 positivity immunohistochemically in $94 \%$ patients. The absence of $\mathrm{HHV}-8$ positivity in the whole study population may be related to a problem with immunohistochemical stain and/or to a lower viral load.

CD31, an endothelial marker, and CD34, which is a marker on fibroblasts and stem cells, are found positive in various vascular tumors, mainly KS, and some fibroblastic tumors, mainly dermatofibrosarcoma protuberance ${ }^{27}$. Doğan Gün et al. ${ }^{10}$ identified CD31 and CD34 positivity immunohistochemically among all patients with the classical KS. In our study, CD31 and CD34 positivity was detected in $98 \%$ and $84.2 \%$ of patients, respectively.

There are some treatment options for KS, namely local and systemic treatments, depending on the extent and clinical form of the disease ${ }^{4}$. Treatments may be applied as monotherapy or combined therapies. The most commonly used monotherapy in our study was cryotherapy (26.3\%). The most commonly used combination therapy was excision and cryotherapy (14.8\%). A study from Turkey identified excision as the most commonly utilized monotherapy treatment, while another study reported that imiquimod combined with cryotherapy was the most commonly applied combination treatment ${ }^{8,9}$. Tsao et al. ${ }^{24}$ applied surgical treatment for 4 among 47 patients with KS and cryotherapy for other three patients. The same study indicated that $30 \%$ of skin lesions of KS showed a complete response and 57\% showed a partial response to the applied treatment. We obtained a partial response in 2 patients for whom we applied radiotherapy as monotherapy.

As for treatment response, the highest response rate was achieved by excision (100\%). This suggests that excision treatment may be primarily considered, particularly for solitary lesions.

Demirel et al. ${ }^{8}$ reported local recurrence in $34 \%$ of patients, with most patients having undergone excision. Furthermore, the authors reported significantly more common recurrences among men. In our study, on the other hand, we identified local recurrence in 4 (5.2\%) patients, of whom 3 had undergone excision and 1 cryotherapy. Three patients with recurrence were male and 1 was female.

As KS is usually seen at advanced age and comorbidities frequently co-exist, mortality is a risk. In our study, 10 (13\%) out of 77 patients died during a mean follow-up of 26.9 months. Of these, one patient died of a secondary malignancy (lymphoma), one patient died due to neutropenia and pneumonia secondary to chemotherapy used for extensive KS, and the remainders due to other medical conditions. Our mortality rate was lower than that reported by Hiatt et al. ${ }^{21}$, which may be due to our follow-up duration being shorter than theirs. Furthermore, deaths due to secondary malignancies and associated medical conditions were more common, with disease-related mortality being lower, as in our study.

\section{Study Limitations}

There are some limitations in our study. Because of retrospective design causality relationship could not be identified. Also there were relatively small numbers of patients enrolled in this study. Large numbers of patients and prospective studies on patients with $\mathrm{KS}$ are necessary for a better understanding of this disease.

\section{Conclusion}

Clinical and histopathological properties and immunohistochemical markers are essential for making an accurate diagnosis of KS. Malignancy screening and follow-up should be carefully performed due to the risk of secondary malignancies associated with $\mathrm{KS}$. A multidisciplinary approach is necessary for disease management and follow-up. There is a need for multicenter studies to examine KS's epidemiological, clinical and treatment properties.

\section{Ethics}

Ethics Committee Approval: The study was approved by the HSU Istanbul Training and Research Hospital, Scientific Research and Publication Ethics Committee (approval number: 932, date: 27.01. 2017).

Informed Consent: It was obtained.

Peer-review: Externally peer-reviewed.

\section{Authorship Contributions}

Concept: A.K.P., A.E.K.A., Design: A.K.P., M.G.K., A.E.K.A., M.S.G., Data Collection or Processing: A.K.P., M.G.K., Analysis or Interpretation: A.K.P., M.G.K., A.E.K.A., C.L., M.S.G., Literature Search: A.K.P., M.G.K., Writing: A.K.P., M.G.K., A.E.K.A., C.L., M.S.G.

Conflict of Interest: No conflict of interest was declared by the authors.

Financial Disclosure: The authors declared that this study received no financial support.

\section{References}

1. North PE, Kincannon J: Vascular Neoplasms and Neoplastic-like Proliferations. Dermatology. Ed. Bolognia JL, Jorizzo JL, Schaffer JV. 3rd ed. St. Louis, Mosby Elsevier, 2012:1932-5.

2. Buonaguro FM, Tornesello ML, Buonaguro L, et al: Kaposi's sarcoma: aetiopathogenesis, histology and clinical features. J Eur Acad Dermatol Venereol 2003;17:138-54.

3. Wu XJ, Pu XM, Kang XJ, et al: One hundred and five Kaposi sarcoma patients: a clinical study in Xinjiang, Northwest of China. J Eur Acad Dermatol Venereol 2014;28:1545-52. 
4. Schneider JW, Dittmer DP: Diagnosis and treatment of Kaposi sarcoma. Am J Clin Dermatol 2017:18:529-39.

5. Akinde $\mathrm{O}$, Obadofin $\mathrm{O}$, Adeyemo $\mathrm{T}$, et al: Kaposi sarcoma among HIV infected patients in Lagos University Teaching Hospital, Nigeria: A 14-Year retrospective clinicopathological study. J Skin Cancer 2016;2016:9368023.

6. Guttman-Yassky E, Bar-Chana M, Yukelson A, et al: Epidemiology of classic Kaposi's sarcoma in the Israeli Jewish population between 1960 and 1998 Br J Cancer 2003;89:1657-60.

7. Stiller CA, Trama A, Brewster DH, et al: Descriptive epidemiology of Kaposi sarcoma in Europe. Report from the RARECARE project. Cancer Epidemiol 2014;38:670-8.

8. Demirel BG, Koca R, Solak Tekin N, ve ark: Klasik Kaposi sarkomu: Yetmiş dört hastanın klinik, demografik özellikleri ve tedavi sonuçlarının değerlendirilmesi. Turkderm 2016;50:136-40.

9. Su Ö, Onsun N, Arda H, ve ark: Klasik Kaposi sarkomlu olgularda klinik özellikler, insan herpesvirüs-8'in varlığı ve tedavi sonuçları. Turkderm 2008:42:122-6.

10. Doğan Gün B, Bahadır B, Ekem TE, ve ark: Klasik Kaposi sarkomu: klinik ve immünohistokimyasal özellikler. Turkiye Klinikleri J Dermatol 2007;17:21-5.

11. Mohanna S, Ferrufino JC, Sanchez J, Bravo F, Gotuzzo E: Epidemiological and clinical characteristics of classic Kaposi's sarcoma in Peru. J Am Acad Dermatol 2005;53:435-41.

12. Weissmann A, Linn S, Weltfriend S, Friedman-Birbaum R: Epidemiological study of classic Kaposi's sarcoma: a retrospective review of 125 cases from Northern Israel. J Eur Acad Dermatol Venereol 2000;14:91-5.

13. Piette WW: The incidence of second malignancies in subsets of Kaposi's sarcoma. J Am Acad Dermatol 1987;16:855-61.

14. Safai B, Mike V, Giraldo G, Beth E, Good RA: Association of Kaposi's sarcoma with second primary malignancies. Cancer 1980;45:1472-9.

15. Paradžik $M$, Bučević-Popović $V$, Šitum $M$, et al: Association of Kaposi's sarcoma-associated herpesvirus (KSHV) with bladder cancer in Croatian patients. Tumour Biol 2014:35:567-72.
16. Lee $\mathrm{S}$, Jang J, Jeon $\mathrm{H}$, et al: Latent Kaposi's sarcoma-associated herpesvirus infection in bladder cancer cells promotes drug resistance by reducing reactive oxygen species. J Microbiol 2016;54:782-8.

17. Anitua $E$, Piñas $L$, Alkhraisat MH: Unusual presentation of Castleman disease in the oral cavity. J Craniofac Surg 2017;28:218-9.

18. Kadıköylü G: Castleman hastalığı ve ekstranodal lenfomalar. Turkiye Klinikleri J Int Med Sci 2007;3:105-13.

19. Wani GM, Ahmad SM, Qayoom S, Khursheed B, Khan AR: Corticosteroid induced, HHV-8 positive Kaposi's sarcoma in a Non-HIV elderly patient. J IMA 2012;44

20. Anderson LA, Lauria C, Romano N, et al: Risk factors for classical Kaposi sarcoma in a population-based case-control study in Sicily. Cancer Epidemiol Biomarkers Prev 2008; 17:3435-43

21. Hiatt KM, Nelson AM, Lichy JH, Fanburg JC: Classic Kaposi sarcoma in the United States over the last two decades: a clinicopathologic and molecular study of 438 non-HIVrelated Kaposi sarcoma patients with comparison to HIV related Kaposi sarcoma. Mod Pathol 2008 21:572-82.

22. Calonje E, Brenn T, Lazar A, McKee PH: McKee's Pathology of the Skin. 4th ed. Philadelphia. Saunders Elsevier, 2012:1729-34.

23. Onak Kandemir N, Doğan Gün B, Barut F, ve ark: Klasik Kaposi sarkomu olgularında histolojik alt gruplar: ön çalışma. Turkderm 2010;44:73-8.

24. Tsao MN, Sinclair E, Assaad D, Fialkov J, Antonyshyn O, Barnes E: Radiation therapy for the treatment of skin Kaposi sarcoma. Ann Palliat Med. 2016:5:298-302.

25. Mesri EA, Cesarman E, Boshoff C: Kaposi's sarcoma and its associated herpesvirus. Nat Rev Cancer. 2010;10:707-19.

26. Leão JC, Caterino-De-Araújo A, Porter SR, Scully C: Human herpesvirus 8 (HHV-8) and the etiopathogenesis of Kaposi's sarcoma. Rev Hosp Clin Fac Med Sao Paulo 2002;57:175-86

27. Pratistadevi K, Ramdial Boris C, Goodlad BJ, John A: McGrath and Alexander Lazar: Specialized techniques in dermatopathology. McKee's Pathology of the Skin. 4th ed. Philadelphia, Saunders Elsevier, 2012:35. 